УДК 622. 331

\title{
ТРАНСФОРМАЦИЯ ОРГАНИЧЕСКОГО ВЕЩЕСТВА ВЕРХОВОГО ТОРФА ПОД ВОЗДЕЙСТВИЕМ ПИВНЫХ ОТХОДОВ
}

\author{
() Л.В. Касимова ${ }^{\text {* }}$, А.Н. Панов ${ }^{2}$, Т.В. Лычева ${ }^{1}$, Н.М. Белоусов \\ ${ }^{1}$ Сибирский научно-исследовательский институт сельского хозяйства \\ и торфра Россельхозакадемии, ул. Гагарина, 3, а/я 1668, Томск, 634050 \\ (Россия), e-mail: sibniit@mail.tomsknet.ru \\ ${ }^{2}$ Институт мониторинга климатических и экологических систем СО РАН, \\ пр. Академический, 10/3, Томск, 634055 (Россия), \\ e-mail: ankislovka@sibmail.com
}

\begin{abstract}
Проведен анализ влияния многократной фильтрации пивной барды через верховой сфагновый торф, смешивания пивной дробины с торфом на его водопоглотительную емкость, агрохимические свойства и качественные показатели полученных продуктов. Установлено значительное накопление минерального азота, подвижного фосфора, водорастворимого органического вещества, аминокислот при хранении торфяных продуктов за счет поглощения минеральных и органических компонентов из пивной барды, а также за счет активного протекания процессов минерализации и трансформации органического вещества торфа под влиянием пивной дробины.

Ключевые слова: верховой торф, отходы пивоваренной промышленности, минерализация, трансформация, торфяной продукт, качественные показатели.
\end{abstract}

\section{Введение}

Решение проблемы разрыва химических связей целлюлозы позволит широко использовать растительное сырье в народном хозяйстве нашей страны, в частности аграрном секторе государства. Многие отходы перерабатывающей промышленности сельскохозяйственной продукции содержит значительное количество жидкой фракции, обогащенной физиологически активными соединениями, которых часто недостает в кормовых рационах сельскохозяйственных животных. Требуются технологические приемы, позволяющие сохранять данный биологический комплекс.

В данном контексте торф необходимо рассматривать в качестве перспективного сырья. Однако торф используется крайне ограниченно. Широкое применение торфа сдерживается содержанием в нем трудноперевариваемой клетчатки, недоступностью гуминовых кислот, аминокислот, витаминов, для извлечения которых требуется химическое разрушение органического вещества торфа и концентрирование продуктов переработки. Перспективным направлением переработки торфа является использование агропромышленных отходов, в том числе отходов пивоварения. Важным параметром, позволяющим использовать верховой торф для утилизации отходов, является его поглотительная способность к макро-, микроэлементам,

Касимова Любовь Владимировна - заведующая лабораторией биологически активных веществ, тел.: (3822) 53-33-90, e-mail:sibniit@ mail.tomsknet.ru Панов Александр Николаевич - старший научный сотрудник, кандидат биологических наук, тел.: (3822) 49-19-07, e-mail ankislovka@ sibmail.com Лычева Татьяна Витальевна - заведующая лабораторией животноводства, тел.: (3822) 53-33-90, e-mail:sibniit@mail.tomsknet.ru

Белоусов Николай Михайлович - директор, тел.: (3822) 53-33-90, e-mail:sibniit@ mail.tomsknet.ru воде, органическим компонентам стоков.

Поглотительная способность торфа зависит от многих факторов: от влажности исходного торфа, его типа и вида, реакции среды, физико-химических свойств органических загрязнителей. Повышенной адсорбционной активностью отличаются торфа моховой и древесной групп. Максимальное значение активности свойственно верховому сфагновому торфу низкой степени разложения [1-4].

\footnotetext{
* Автор, с которым следует вести переписку.
} 
Технология пивоварения сопровождается наличием больших объемов отходов производства, которые требуют их утилизации. Производство пива предусматривает обработку зерна, в результате которой крахмал расщепляется до моносахаров. Микробиологические процессы обогащают отходы пивоварения полноценным белком, набором витаминов, особенно группы В, и значительным количеством незаменимых аминокислот. Сырье содержит биологически активный комплекс элементов, способный оказывать положительное влияние на метаболизм сельскохозяйственных животных. Поэтому переработка отходов пивоваренной промышленности требует взвешенного подхода [5].

Цель настоящей работы - изучение взаимодействия верхового торфа с пивной бардой и пивной дробиной на процессы сорбции, минерализации и трансформации органического вещества торфа и качество получаемых торфяных продуктов при температуре $18-22^{\circ} \mathrm{C}$.

\section{Экспериментальная часть}

Эксперимент был проведен в СибНИИСХиТ Россельхозакадемии. Объектом исследования служил верховой сфагновый торф месторождения «Темное» Томского района Томской области. В состав верхового торфа входит 29-37\% легкогидролизуемых и водорастворимых веществ, около 4\% битумов, 19-23\% гуминовых кислот, 13-19\% фульвокислот, 24-27\% целлюлозы и лигнина, 6,5\% аминокислот. В торфе содержится 8-10\% макро- и микроэлементов. На долю кальция приходится 7,8\% сухого вещества торфа, натрия $0,2 \%$, содержание железа составляет 500 мг/кг, цинка -5 мг/кг, меди - 4 мг/кг.

В работе использованы пивная барда и пивная дробина, являющиеся отходами пивоваренного завода г. Томска.

Методика проведения фильтрации стоков через торф заключалась в том, что через 20,0 г верхового торфа влажностью 17\% пропускали 100 мл стоков пивоваренного завода г. Томска. Фильтрацию проводили в лабораторных условиях многократно до появления постоянного объема фильтрата. Полученный торфяной продукт оставляли на хранение в течение 15 суток. Свойства полученного продукта изучали во влажном и сухом состоянии.

Процессы минерализации азотсодержащего органического вещества верхового торфа отслеживали по изменению содержания N-NH4, которое определяли по ГОСТ 27894.0-88 - ГОСТ 27894.11-88.

Процессы минерализации фосфорсодержащего органического вещества торфа характеризовали по накоплению подвижного фосфора, определенного по ГОСТ 27894.0-88 - ГОСТ 27894.11-88 [4].

Качество полученного торфяного продукта в качестве кормовой добавки оценивали по общепринятым показателям: по содержанию протеина, жира, сахара, клетчатки, БЭВ и др. [6-8]. Возможность применения продукта в качестве органического удобрения рассматривали по содержанию валовых и подвижных форм элементов питания. Расчет дозы внесения продукта как удобрения проводился по содержанию валового и подвижного азота.

Определение каждого показателя проведено в трехкратной повторности. Для статистической обработки данных использовали программу MS Excel.

\section{Обсуждение результатов}

Химический состав промышленных стоков. Промышленные отходы, получаемые при пивоварении, можно рассматривать в качестве перспективного сырья для производства кормовой добавки. Количество сухого остатка в жидкой фракции достоверно отличается от содержания ее в пивной дробине. Особенности технологии пивоварения требуют большого количества воды, которая способна вымывать растворимые вещества из исходного сырья. Процессы микробиологического брожения приводят к изменению химических связей белков, углеводов и жиров зерна, что также способствует переходу биологических комплексов в жидкую фракцию, которая по технологическим требованиям уходит в отходы, обогащая их важными компонентами. Количество аминокислотного азота находится практически на уровне 98 мг/л, что указывает на высокое содержание белка в анализируемых стоках (табл. 1).

Пивная дробина содержит зерновые оболочки, нерастворимые частицы зерна, почти весь жир и белок зерна и представляет собой сухой экстрагированный остаток ячменного солода. Низкое содержание сухого и прокаленного остатка в пивной дробине и относительно высокое содержание их в жидкой фракции свидетельствуют о глубокой переработке зерна.

Содержание азота, фосфора, калия и кальция в отходах пивоварения показывает, что пивная барда содержит больше биогенных элементов, чем пивная дробина, что также свидетельствует об активном переходе растворимых биологически активных соединений в жидкую фракцию (табл. 2). 
Таблица 1. Некоторые показатели отходов пивоваренного завода

\begin{tabular}{|c|c|c|c|c|c|c|}
\hline \multirow{2}{*}{ Показатель } & \multirow{2}{*}{$\begin{array}{c}\text { Плотность, } \\
{\text { г } / \mathrm{cm}^{3}}^{3}\end{array}$} & \multirow{2}{*}{ Влажность, \% } & \multicolumn{2}{|c|}{ Остаток, г/л } & \multirow{2}{*}{$\begin{array}{c}\text { Сахара, мг на } 1 \text { л } \\
\text { раствора }\end{array}$} & \multirow{2}{*}{$\begin{array}{c}\text { N-аминокислот, мI } \\
\text { на } 1 \text { л раствора }\end{array}$} \\
\hline & & & Сухой & Прокаленный & & \\
\hline $\begin{array}{l}\text { Жидкая } \\
\text { фракция }\end{array}$ & $0,995 \pm 0,0$ & $96,70 \pm 9,13$ & $32,99 \pm 9,13$ & $1,54 \pm 0,26$ & $96,5 \pm 3,54$ & $98,15 \pm 0,92$ \\
\hline $\begin{array}{l}\text { Пивная } \\
\text { дробина }\end{array}$ & - & - & $0,17 \pm 0,02$ & $0,06 \pm 0,01$ & - & - \\
\hline
\end{tabular}

Таблица 2. Содержание минеральных веществ в промышленных стоках, мг/100 г а.с.в.

\begin{tabular}{c|c|c|c|c}
\hline Показатель & $\mathrm{N}$ & $\mathrm{P}$ & $\mathrm{K}$ & $\mathrm{Ca}$ \\
\hline Пивная барда & $0,0112 \pm 0,0014$ & $0,02101 \pm 0,0006$ & $0,00106 \pm 0,00007$ & $0,03147 \pm 0,0018$ \\
Пивная дробина & $0,00032 \pm 0,00007$ & $0,000488 \pm 0,0002$ & $0,000118 \pm 0,000024$ & $0,003182 \pm 0,00007$ \\
\hline
\end{tabular}

Состав и свойства торфяного продукта на основе верхового торфа и отходов пивоварения. Многократная фильтрация пивной барды через верховой торф привела к изменению показателя плотности фильтрата. На высокую степень очистки стоков от минеральных и органических компонентов указывает изменение показателя плотности фильтрата, который составлял 0,9910 г/см, что соответствует показателю плотности питьевой водопроводной воды.

Поглощение верховым торфом воды из пивной барды. Процессы фильтрации показали, что 20 г верхового торфа влажностью 17\% поглощали 75 мл жидкости из 100 г пивной барды. Относительно высокая поглотительная способность верхового торфа к жидкости пивной барды объясняется тем, что санитарная обработка промышленных емкостей щелочными препаратами способствует смещению рН в щелочную среду. В щелочной среде активируется и вступает в обмен ионы Н+ гидроксильных групп, повышая общую емкость поглощения торфа. При фильтрации стоков 1 г исследуемого торфа поглощал 3,75 г жидкости из пивной барды. При этом верховой торф использовал примерно $30 \%$ от своей емкости поглощения. Снижение поглощения воды связано с размерами молекул органических компонентов пивной барды, которые способствуют закупорке пор сфагнового верхового торфа. В процессе фильтрации происходит набухание структур торфа, что также снижает емкость поглощения верхового торфа к воде.

Реакция среды. Исходный торф имел $\mathrm{pH}$, равный 3,2, что свидетельствует о кислой среде верхового торфа, используемого в опыте. При санитарной обработке оборудования, используемого в процессе пивоварения, например содой, реакция среды жидкой фракции повышается. Поэтому жидкая фракция пивной барды способствует развитию местной популяции микрофлоры верхового торфа, развивающейся в нейтральной или щелочной среде. Известно, что рН среды пищеварительного тракта ниже 5 ингибирует физиологическую активность симбиотической микрофлоры. Твердая фракция пивной дробины способствовала изменению реакции среды торфяного продукта в меньшей степени, чем пивная барда (рис. 1).

Содержание валовых форм элементов питания. Анализ торфяного продукта после фильтрации пивной барды показал, что количество азота в торфяном продукте возросло в 3,9 раза и достигло 3,50\%. Внесение пивной дробины в верховой торф способствовало накоплению азота в 3,1 раза, или до $2,76 \%$. Пивная барда создавала более благоприятные условия для накопления азота в торфяном продукте.

Процессы поглощения фосфора и калия при многократном пропускании стоков через верховой торф имеют специфику. Процессы сорбции фосфора при внесении пивной дробины снижали содержание фосфора в торфяном продукте относительно контроля на 6,3\%. Пивная барда, напротив, способствовала увеличению содержания фосфора в торфяном продукте на 22,7\%. Содержание калия увеличилось в 2,76-4,69 раза и составило 0,36-0,61\% (табл. 3). Более низкие показатели содержания фосфора и калия в торфяном продукте получены после смешивания верхового торфа с пивной дробиной. Относительно высокая влажность и содержание элементов питания в пивной барде способствовали оптимизации биохимических процессов в исследуемом торфяном продукте и более высокой сорбцией элементов питания.

Содержание минерального азота. После процессов фильтрации пивной барды и смешивания пивной дробины с верховым торфом полученные торфяные продукты хранились при комнатной температуре в течение 15 суток. В процессе хранения исследуемых торфяных продуктов произошло заметное снижение содержания аммонийного азота в 2,57-3,52 раза, и отсутствовал нитратный азот, что обусловлено формированием в смеси верхового торфа с отходами пивоварения восстановительных условий по сравнению с исходным торфом. 


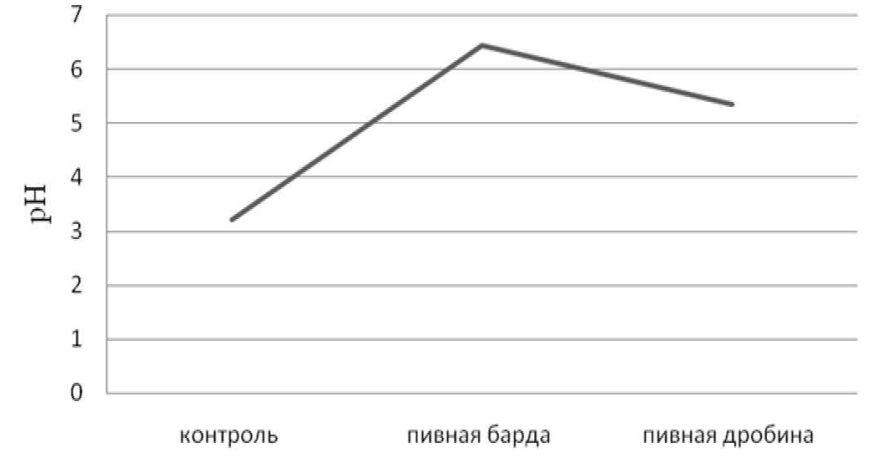

Рис. 1. Влияние многократной фильтрации стоков пивоваренного завода через верховой торф на изменение реакции среды

Таблица 3. Влияние отходов пивоваренного завода на содержание валовых форм элементов питания в получаемых торфяных продуктах

\begin{tabular}{l|c|c|c}
\hline \multirow{2}{*}{\begin{tabular}{c} 
Вариант смеси верхового торфа \\
\multicolumn{1}{c}{ с отходами }
\end{tabular}} & \multicolumn{3}{|c}{ Содержание валовых форм элементов питания в торфянм продукте, \% на а.с.в. } \\
\cline { 2 - 4 } & $\mathrm{N}$ & $\mathrm{P}_{2} \mathrm{O}_{5}$ & $\mathrm{~K}_{2} \mathrm{O}$ \\
\hline Верховой торф (контроль) & 0,9 & 1,1 & 0,13 \\
Верховой торф + пивная барда & 3,50 & 1,35 & 0,61 \\
Верховой торф + пивная дробина & 2,76 & 1,03 & 0,36 \\
\hline
\end{tabular}

Содержание подвижного фосфора. Внесение отходов пивоваренного завода в верховой торф и хранение смесей привело к возрастанию подвижного фосфора относительно исходного торфа с 0,117 до 0,753-0,923 г, или в 6,4-7,8 раза (табл. 4).

Содержание подвижного фосфора. Исходное содержание фосфора в верховом торфе составляло 0,117 г на 100 г а.с.в. Обработка верхового торфа пивной бардой привела к росту содержания фосфора в исследуемой смеси в 7,9 раза, пивная дробина обеспечила рост анализируемого показателя в 6,43 раза. Максимальное накопление фосфора наблюдалось в смеси торфа с пивной бардой. Накопление фосфора в торфяных продуктах обусловлено поглощением его из отходов пивоварения, а также минерализацией фосфорсодержащего органического вещества верхового торфа.

Водорастворимое органическое вещество. Процессы трансформации органического вещества верхового торфа, пропитанного пивной бардой и смешанного с влажной пивной дробиной, в ходе хранения привели к увеличению содержания водорастворимого органического вещества торфа (табл. 4). Содержание его в торфяных продуктах составляло 6191,53 и 7482,36 мг/100 г а.с.в., что соответствует увеличению его в 22-27 раз относительно контроля. Максимальное увеличение показателя обеспечило внесение пивной дробины за счет собственного водорастворимого органического вещества.

Качественные показатели торфяных продуктов, обогащенных отходами пивоваренного завода. Параметры качественных показателей полученных торфяных продуктов приведены в таблице 5. Обработка верхового торфа пивной бардой способствовала увеличению сухого остатка в торфяном продукте на 16\%. Внесение пивной дробины обогащает торфяной продукт сухим остатком на 56\%, или на 34\% больше, чем пивная барда. Дрожжи пивной дробины продолжают определенное время свою жизнедеятельность, обогащая пивную дробину и, соответственно, торфяной продукт биологически активными веществами.

Клетчатка является сложным углеводным комплексом растительного организма. Пищеварение травоядных животных ориентировано на поступление определенного количества клетчатки. Симбиотическая микрофлора пищеварительного тракта обеспечивает жвачных полноценным белком. Основным источником энергии симбиотической микрофлоры рубца сельскохозяйственных и травоядных животных является именно клетчатка. Недостаток клетчатки ведет к снижению моторной функции кишечника, избыток клетчатки способствует быстрой эвакуации кормов из пищеварительного тракта животных. Физиологическая норма содержания клетчатки в кормовом рационе должна находиться в пределах 11-17\% от сухого вещества корма. Исходный торф содержал $28 \%$ клетчатки, что превышает физиологически обоснованную норму, но значительная часть ее не усваивается животными. Обработка верхового торфа отходами пивоварения привела к трансформации углеводного комплекса, что снизило содержание клетчатки до 19-21\%. Интересно отметить тот факт, что пивная дробина, содержащая клетчатку, способствовала не накоплению, а снижению количества клетчатки в исследуемом торфяном продукте. 
Таблица 4. Накопление в торфяных продуктах подвижных форм элементов питания при внесении в верховой торф пивоваренных отходов

\begin{tabular}{|c|c|c|c|c|c|}
\hline \multirow[t]{2}{*}{ Вариант опыта } & \multirow[t]{2}{*}{ Влажность, \% } & \multicolumn{4}{|c|}{$\begin{array}{c}\text { Содержание минеральных и органических компонентов } \\
\text { в исследуемых торфяных продуктах, мг/100 г а.с.в. }\end{array}$} \\
\hline & & $\mathrm{N}-\mathrm{NH}_{4}$ & $\mathrm{P}_{2} \mathrm{O}_{5}$ & $\mathrm{~N}-\mathrm{NO}_{3}$ & C в.p. \\
\hline Верховой торф (контроль) & $40,75 \pm 1,23$ & $140,7 \pm 4,65$ & $117 \pm 2,31$ & $3,43 \pm 0,09$ & $271,2 \pm 29,6$ \\
\hline Верховой торф + пивная барда & $77,9 \pm 0,99$ & $54,60 \pm 5,45$ & $923,26 \pm 14,98$ & 0 & $6191,53 \pm 407,05$ \\
\hline Верховой торф + пивная дробина & $70,32 \pm 6,06$ & $39,96 \pm 5,14$ & $753,46 \pm 78,80$ & 0 & $7482,36 \pm 3050,4$ \\
\hline
\end{tabular}

Таблица 5. Качественные показатели торфяных продуктов состава верховой торф + стоки и отходы пивоваренной промышленности

\begin{tabular}{|c|c|c|c|c|c|c|c|c|}
\hline \multirow[b]{2}{*}{ Вариант опыта } & \multicolumn{8}{|c|}{$\begin{array}{c}\text { Качественные показатели торфяного продукта верховой торф + стоки и отходы пивоваренного } \\
\text { завода, \% на сухое вещество }\end{array}$} \\
\hline & $\begin{array}{c}\text { Влаж- } \\
\text { ность, \% }\end{array}$ & $\begin{array}{l}\text { Сухое ве- } \\
\text { щество, \% }\end{array}$ & $\begin{array}{l}\text { Клетчатка, } \\
\%\end{array}$ & $\begin{array}{l}\text { Сырой } \\
\text { жир, \% }\end{array}$ & $\begin{array}{c}\text { Азот ами- } \\
\text { нокислот- } \\
\text { ный** }\end{array}$ & БЭВ, \% & $\begin{array}{l}\text { Витамин С, } \\
\text { мг\% }\end{array}$ & $\begin{array}{c}\text { Сырой } \\
\text { протеин, \% }\end{array}$ \\
\hline $\begin{array}{l}\text { Верховой торф } \\
\text { (контроль) }\end{array}$ & 5,0 & 8,0 & 28,1 & 1,3 & 130,7 & 49,0 & 42,4 & 5,6 \\
\hline $\begin{array}{l}\text { Верховой торф + } \\
\text { пивная барда }\end{array}$ & $5,4 \pm 0,24$ & $9,28 \pm 0,48$ & $20,98 \pm 0,12$ & $1,21 \pm 0,04$ & $329,8 \pm 5,79$ & $46,61 \pm 4,02$ & $126,81 \pm 2,01^{*}$ & $21,88 \pm 3,51 *$ \\
\hline $\begin{array}{l}\text { Верховой торф + } \\
\text { пивная дробина }\end{array}$ & $5,09 \pm 0,60$ & $12,51 \pm 0,93$ & $19,02 \pm 0,52$ & $1,39 \pm 0,03$ & $447,2 \pm 2,89^{*}$ & $51,22 \pm 0,71$ & $240,89 \pm 2,51^{*}$ & $17,03 \pm 0,71 *$ \\
\hline
\end{tabular}

Примечания: * достоверное отличие показателя исследуемого торфяного продукта; **мг D-тирозин на 100 г с.в.

Жиры обладают очень разнообразным метаболическим действием. Физиологическая норма содержания сырого жира в сухом веществе корма должна колебаться в пределах от 2 до 4\%. Верховой торф трудно рассматривать в качестве источника жиров. Однако внесение пивной дробины в верховой торф привело к увеличению сырого жира относительно контроля на 6,9\%, пивная барда способствовала снижению данного показателя. Повышение жира объясняется микробиологической деятельностью дрожжей, оставшихся на пивной дробине.

Азот аминокислотный является важным показателем, характеризующим протекание биохимических процессов в смесях верхового торфа и отходов пивоварения. Процесс синтеза азота аминокислотного со 130,7 мг/100 г а.с.в. привел к возрастанию азота до 329,8-447,2 мг/100 г а.с.в., что превышает исходный показатель в 2,52-3,42 раза. Максимальное количество азота аминокислотного наблюдалось в смеси верхового торфа с пивной дробиной, что свидетельствует о наличии благоприятных условий синтеза азота.

До настоящего времени проблема белкового дефицита кормовых и пищевых рационов остается актуальной. Обогащение кормовых рационов протеином позволит получить качественную сельскохозяйственную продукцию. Ценность протеина состоит в том, что протеин содержит набор аминокислот, что облегчает синтез видовых белков в животном организме. Оптимальное количество протеина должно находиться в пределах 12-15\%. Исходный торф содержал 5,6\% на сухое вещество, добавление отходов пивоварения привело к росту содержания сырого протеина в 3,04-3,90 раза и достигало 17,03-21,88\%. Максимальное количество сырого протеина находилось в торфяном продукте с пивной бардой.

На одну часть сырого протеина должно приходиться от 3 до 5 частей БЭВ. Внесение пивной дробины в верховой торф позволило получить соотношение $1: 3$, пивной барды - $1: 2,1$. Пивная дробина, внесенная в торф, способствовала созданию оптимальных условий для протекания биохимических процессов.

Витамины - неотъемлемый элемент механизма метаболизма сельскохозяйственных животных. Внесение в верховой торф отходов пивоварения способствовало росту витамина С в торфяном продукте в 2,99-5,58 раза. Максимальное количество витамина С зарегистрировано в торфяном продукте, обработанном торфяной дробиной.

Качественные показатели торфяного продукта как торфяного удобрения: содержание валового азота 2,76-3,50\%, валового фосфора - 1,03-1,35\% и валового калия - 0,36-0,61\% на а.с.в. По содержанию валового азота торфяной продукт следует вносить в почву в качестве органического удобрения в дозе 1,7-2,5 т сухого вещества, или 5,7-8,3 т/га продукта влажностью примерно 70\%.

\section{Заключение}

Фильтрация пивной барды через верховой торф и обогащение верхового торфа пивной дробиной позволили: 
- повысить содержание сырого протеина в 3,04-3,90 раза, аминокислотного азота - в 2,52-3,42 раза, валового азота - в 3,0-3,88 раза, валового калия - в 2,76-4,69 раза, водорастворимого органического вещества - 22-27 раз относительно аналогичных показателей в верховом торфе;

- получить торфяной продукт, содержащий 17-21\% сырого протеина, 126,81-240,89 мг-\% витамина C, 329,8-447,2 мг/100 г а.с.в. азота аминокислот, 1,21-1,39\% сырого жира, 19,02-20,98\% клетчатки, 46,61$51,22 \%$ БЭВ;

- получить торфяное удобрение с содержанием 2,76-3,50\% валового азота, 1,03-1,35\% валового фосфора, 0,36-0,61\% валового калия.

\section{Сиисок литературы}

1. Архипов В.С., Лобова Ю.А. Адсорбционные свойства торфа // Болота и биосфера : матер. 7-й Всерос. с международным участием школы молодых ученых. Томск, 2007. С. 8-18.

2. Плаксин Г.В., Левицкий В.А., Шипилин Д.В., Третьяков А.Г. Сорбенты на основе сапропелей для очистки воды от нефтепродуктов и органических соединений. Томск, 2003. С. 108-111.

3. Александров Б.М., Гревцев Н.В., Горбунов А.В., Гревцева И.Н. Использование торфа при переработке промышленных отходов. Томск, 2003. С. 114-115.

4. ГОСТ 27894.0-88 - ГОСТ 27894.11-88. Торф и продукты его переработки для сельского хозяйства. Методы анализа.

5. Булгаков Н.И. Биохимия солода и пива. М., 1976. 357 с.

6. ГОСТ 26176-91. Корма, комбикорма. Методы определения растворимых и легкогидролизуемых углеводов.

7. ГОСТ 13496.17-95. Корма. Методы определения каротина.

8. ГОСТ 10846-91. Зерно и продукты его переработки. Метод определения белка.

9. Главачек Ф., Лхотский А. Пивоварение. М., 1977. 622 с.

Поступило в редакцию 12 июля 2011 г.

Kasimova L.V..$^{{ }^{*}}$, Panov A.N. ${ }^{2}$, Lycheva T.V. ${ }^{l}$, Belousov N.M. ${ }^{l}$ TRANSFORMATION OF ORGANIC SUBSTANCES OF HIGH MOOR PEAT UNDER BEER WASTE

${ }^{1}$ Siberian Research Institute of Agriculture and Agricultural Sciences peat, Gagarina st., 3, p.o.b.1668, Tomsk, 634050

(Russia),e-mail: sibniit@ mail.tomsknet.ru

${ }^{2}$ Institute of Monitoring of Climatic and Ecological Systems SB RAS, pr. Akademicheskii, 10/3, Tomsk, 634055 (Russia), e-mail; ankislovka@sibmail.com

The effect of multiple filtration of the beer brewing wastes by the high moor peat and their mixtures on water absorbing capacity, agrochemical properties, and qualitative characteristics of received products were analyzed. Increases of mineral nitrogen, mobile phosphorus, water saluted organic substance, and aminoacids by absorption of mineral and organic compounds and active mineralization and transformation of peat organic substance.

Keywords: high moor peat, beer brewing wastes, mineralization, transformation, peat product, qualitative characteristics.

\section{References}

1. Arkhipov V.S., Lobova Iu.A. Bolota i biosfera : mater. 7-i Vseros. s mezhdunarodnym uchastiem shkoly molo-dykh uchenykh. [Marshes and the Biosphere: Proceedings of the 7th All-Russian schools with international participation of young scientists.]. Tomsk, 2007, pp. 8-18. (in Russ.).

2. Plaksin G.V., Levitskii V.A., Shipilin D.V., Tret'iakov A.G. Sorbenty na osnove sapropelei dlia ochistki vody ot nefteproduktov $i$ organicheskikh soedinenii. [Sorbents based on sapropel to purify water from oil and organic compounds]. Tomsk, 2003, pp. 108-111. (in Russ.).

3. Aleksandrov B.M., Grevtsev N.V., Gorbunov A.V., Grevtseva I.N. Ispol'zovanie torfa pri pererabotke promyshlennykh otkhodov. [The use of peat in the processing of industrial waste]. Tomsk, 2003, pp. 114-115. (in Russ.).

4. GOST 27894.0-88 - GOST 27894.11-88. Torf i produkty ego pererabotki dlia sel'skogo khoziaistva. Metody analiza. [Peat and its products for agriculture. Methods of analysis.]. (in Russ.).

5. Bulgakov N.I. Biokhimiia soloda i piva. [Biochemistry of malt and beer]. Moscow, 1976, 357 p. (in Russ.).

6. GOST 26176-91. Korma, kombikorma. Metody opredeleniia rastvorimykh i legkogidrolizuemykh uglevodov. [Feed, feed. Methods for the determination of readily soluble and carbohydrates]. (in Russ.).

7. ГОСТ 13496.17-95. Korma. Metody opredeleniia karotina. [Feed. Methods for determination of carotene]. (in Russ.).

8. ГОСТ 10846-91. Zerno i produkty ego pererabotki. Metod opredeleniia belka. [Grain and its products. Method for the determination of protein.]. (in Russ.).

9. Glavachek F., Lkhotskii A. Pivovarenie. [Brewing]. Moscow, 1977, 622 p. (in Russ.).

\footnotetext{
* Corresponding author.
} 